\title{
Reflection and Innovation of Undergraduate Teaching in E-Commerce
}

\author{
Fengna Ge \\ Research Institute of Management Science and Engineering, Henan University, Kaifeng, China \\ Email: gena2002@163.com
}

Received 25 May 2016; accepted 24 June 2016; published 27 June 2016

Copyright (C 2016 by author and Scientific Research Publishing Inc.

This work is licensed under the Creative Commons Attribution International License (CC BY). http://creativecommons.org/licenses/by/4.0/

c) (i) Open Access

\begin{abstract}
As a technical and commercial revolution, e-commerce has an impact on the development of social economy more and more profoundly, and changes men's business model and lifestyle fundamentally. Shortages of talents on e-commerce have become a "bottleneck" restricting China's e-commerce development. However, undergraduate teachings in e-commerce have some shortcomings. Out of line with social demands, trainings for talents are of low quality. Therefore, reflecting problems of current undergraduate teachings in e-commerce, thus to explore solutions to these problem is undoubtedly of great theoretical and practical significance.
\end{abstract}

\section{Keywords}

\section{E-Commerce, Personnel Training, Reflection, Solution}

\section{Introduction}

As the 21st century's most promising business model, e-commerce has a profound effect on all walks of life, and makes huge profits. The data from China National Network Information Center (CNNIC) shows that national e-commerce transactions in 2007 amounted to 2.17 trillion yuan, increasing by 90 percent over the last year, the number of users of online shopping reached 63.29 million by the end of June in 2008, rising by 36.4\% within six months, and the overall e-commerce site users had risen from 90 million to 98 million by the end of 2008. In July of 2010, the latest data from CNNIC shows that there is a rapid increase in e-commerce transactions, the average annual growth rate arriving to $68 \%$, online shoppers to 142 million, the utilization rate increasing to $33.8 \%$. However, experts predict that over the next 10 years, China's e-commerce talents shortage will be more than 200 million people (Feng, 2010). These data show that e-commerce is of increasingly important in the development of national economy, which will produce great practical demands for e-commerce talents, thus the cultivation of talents is very urgent. 


\section{The Present Situation of the Development of Our Country's College E-Commerce Courses}

Facing huge demands, many universities have established e-commerce specialty covering different training levels, such as courses for junior college students, undergraduates, masters and doctoral students. Course for undergraduates is the primary training level. The ministry of education approved 13 colleges to establish e-commerce specialty for undergraduats in June of 2001. The number of colleges admitted increased to 96 in 2002, to 153 in 2003, to near 200 in 2004. The speed of growth is very fast [1]. So far, there have been more than 300 universities and nearly 1000 colleges setting up e-commerce specialty [2]. The scale of development is very big and the speed is fast. However, the career prospects for graduates specialised in e-commerce is not ideal. Relevant departments predict that in the next 10 years, annual demand for talents on e-commerce is about 200 thousand people. However, the current output of talents is less than 100 thousand, universities and various types of training agencies included. The gap is huge. But surveys found that the employment rate of graduates specialised in e-commerce is far below the national average level of university students', which is only $20 \%$ a year [3]. High demand doesn't lead to high employment. The main reason is that trainings for professional fail to meet social needs.

\section{Main Problems Existing in E-Commerce Teachings for Undergraduate}

Electronic commerce is a comprehensive major involved in management science, computer science, marketing, and other disciplines, and is both theoretical and practical. Because it's a short time since e-commerce was setting up and the subject is affected by others' teaching model, the following problems is existing in the undergraduate teachings of e-commerce.

\subsection{Training Target Unclear, Positioning Fuzzy}

Clear training targets are the premise of talent training. Teachings will lack focus and direction and what kind of people trainees will be is unknown without a clear target. What on earth should undergraduate electronic commerce teachings emphasize? Technology, business or both? At present, the three situations are all existing. Some science and engineering colleges focus on technology, some university of liberal arts on business, and some comprehensive university on both. $t$ is very common that e-commerce teachings are setting up according to their respective characteristic and superiority, which lead to teaching effectiveness, low employment rate and the situation that theoretical teaching and the industry requirements are disjointed.

\subsection{Delayed Development of Teaching Materials, Repeatable Contents}

As a new thing, the course teachings and practice develop simultaneously, so the construction of teaching material is hard to avoid problems. One is that part of the teaching material is just scissors-and-paste job from computer, management, economy, lack of application and pertinence. Two is that part of teaching material is not practica. E-commerce is a comprehensive and practical activity involved in specific behaviors such as network marketing, online transactions, electronic payment and express logistics. But the present materials are relatively old and single, emphasize on theory and neglect practice. They can't fully involved in all contents of e-commerce and combine with practice. In addition, electronic commerce itself has been developing continuously. There appears new areas and new situations, as soon as a textbook has just published, which leads teaching material always to lag behind. For example, some website listed by teaching materials has dramatically changed, or even closed. Three is the repeatable contents. Though different colleges published materials according to their respective situations, they face the same problem that they are not systematic, normalized and practical. Repetition and conflict are still existing. Contents of different courses are simply stacked, lack of authoritative and practical teaching materials. The last is that the construction of teaching materials lack coordination. Universities acts their own way, which scatters research resources and go against consensus and results promotion [4].

\subsection{Chaos Curriculum, Deviate from Target}

Curriculum is the foundation of talent training. E-commerce develops faster and faster and involves in more and more fields. At the same time, the industry is changing rapidly. Technology, application, demand, and business 
development are changing and developing, so the curriculum should be set ahead, as well as correspond to actual need of the industry. At present, e-commerce courses set by many domestic universities are not enough scientific and reasonable, mainly displays in the following ways: One is that universities ignore the training goal, don't consider professional requirements. Courses are set up according to their respective advantages. Courses involving business only account for $20 \%$ of all e-commerce courses set by general colleges. Science and engineering colleges focus on computer cultivations, while colleges of art on management. The psroportion of professional course is too low [5]. In some colleges, computer courses accounted about $80 \%$, but business course are very few. In fact, the nature of electronic commerce is business. Computer and network are just tool and carriers. The second is that theory outweighs practice. Electronic commerce is a discipline with strong applicability. Practice teaching should be prominent in all curriculums, but most colleges and universities are lack of the attention. In some institutes, practice class hours are insufficient. Some even don't have practical teaching. Others though set practice teaching but failed to ensure effect. This kind of course system far lag behind the development of electronic commerce, which lead to weak basic skills, insuffient practice experience and that students' professional knowledge is not solid, so trainees can't satisfy the need of enterprises.

\subsection{Single Teaching without Accordance with Practice}

Electronic commerce is a comprehensive discipline, theoretical and practical, which emphasize theory and practice combine closely. Therefore, rich and effective practice teaching is essential. But at present many problems still exist in practice teachings. The first is that the attention is not enough. Affected by "standard knowledge" and "discipline center", traditional classroom teaching patterns are used in most teachings, where theory is emphasized and practice is neglected, resulting in that students lack learning interest. Moreover, because theory isn't combine with practice, teaching is effectiveness. Some colleges lack environment and means to conduct practical teaching, because of insuffient attention and capital investment. The second is that means is single, teaching becomes formalistic. Although some universities set up e-commerce laboratory and install relevant simulation experiment systems, the software itself often deviate from actual business environment and subsequent investment isn't enough. As a result, hardware and software can't update in time and teaching effect is difficult to guarantee. Besides, experiment projects lack comprehensive and innovative projects, only relating to basic knowledge points and ignoring students' innovation and design sensitivity [5]. The rigid practice teaching form is difficult to cultivate students' flexible operation skill and thier reality perception of the operation.

\subsection{Weak Teaching Force Insufficient Ability}

Excellent teachers teams can guarantee the quality of electronic commerce teaching. To cultivate compound applied talents who have good knowledge of management, economics and trade theory and master e-commerce, computer science and technology, which is needed by e-commerce industry, teachers engaged in the electronic commerce is the key. Teachers should have professional knowledge and skills, and must be familiar with the actual electronic commerce work process. Above all, they can integrate with both in teachings. However, the requirement is difficult to meet now. First of all, lack high-level teachers. Since e-commerce is a new major, most teachers are young, whose education degrees and titles are low and teaching experences are deficient. ven some teachers are newly graduate, who lacks profound theoretical knowledge and rich teaching experience, as well as e-commerce practice experience [6]. Teachers don't have thorough grasp of professional knowledge. Educators and the educated study simultaneously. Finally, lack practice and training. At present, most of the teachers don't have enough opportunities to practice in enterprises, so they don't have clear cognition of requirements. Teaching isn't in coincidence with practice. Because e-commerce isn't set up for a long time, training and learning opportunities offered by institutions and industry associations are not much, which handicap teachers to improve their ability.

\section{Measures to Strengthen Undergraduate Electronic Commerce Teachings}

Reconsidering problems in our country's undergraduate electronic commerce teachings, we must adopt countermeasures pertinently. Only innovating and developing in teachings can social needs be gradually satisfied and qualified electronic commerce talents be trained. 


\subsection{Determine Training Target and Subject's Position}

Higher education trains talents to serve society and market. Therefore, industry requirements for talents should be determined. Position subject oriented towards the need of market. At present, there are three kinds of talents needed by industry: Talents specialised in technology, business and comprehensive administration. Technical talents, who can be trained by computer courses of science and engineering colleges, don't need special trainings. Business talented people should be trained by business and administration colleges. Comprehensive administration talents have abundant experiences, which graduates can't be competent for and can't be achieved by undergraduate education. Therefore, for most universities, training target should be talents expert in business, who are applied talents with interdisciplinary knowledge and familiar with electronic business specific application. On this basis, further breakdown industry is needed. Practical talents are cultivated by stratified trainings. For example, most large enterprises demand for professional personnel. Small and medium-sized enterprises need skilled talents familiar with network marketing. Only by making different training programs based on different needs can qualified personnels be cultivated, who truly satisfy industry's need.

\subsection{Plan Top Design Construct Curriculum System}

Curriculum is the key to electronic commerce teaching. Curriculum system is the core of the talent training scheme. Therefore, curriculum system must be paid high attention when making talent training scheme, and treat it as the primary work of planning electronic commerce teachings. That electronic commerce is applied discipline should be given full consideration to through the construction of curriculum system. Let the curriculum system be more continuous, related and scientific. In specific, curriculum system can be divided into three modules: Fundamental course, industry applications course and comprehensive practice course. The three are complements. None can be left. Professional foundation courses include economic management course (modern enterprise operation and management, etc.), business course (network marketing, etc.) and computer and network technical courses (web design and production, web design and maintenance, database principle, graphic image processing, etc.). Through the study of professional courses, reserve knowledge for subsequent courses. Industry application course includes the introduction of e-commerce, accounting, finance, foreign trade and business. Through the course, students understand knowledge involved in all aspects of electronic commerce practice. Comprehensive practice includes electronic business case analysis, enterprise practice, electronic business operation, focusing on the examination of learned theory knowledge, previewing for working in the industry.

\subsection{Pay Attention to the Combination of Teaching and Practicing, Strengthen the Construction of Teaching Material}

Teaching material is the basis and support of teachers' teaching and students' learning. We must make good construction of teaching materials, compile authoritative textbooks which combine theory with practice, track frontiers, and grasp key points. First, the idea of comprehensive discipline should be fully embodied in the process of compiling teaching materials. Pertinency and application stand out. Theory knowledge is involved at a degree just satisfying the need. Compile textbook according to talents training target and professional capacity requirements. Basic knowledge which students is able to understand and master and will use in the future work should be in the textbooks. Second, ensure the practicality and operability of the content in the process of compiling teaching materials. E-commerce is an applied science. Most of professional graduates are in the skilled operation post, very little in theory research and teaching. Therefore, comprehensive theory and strong practicality should be reflected in the process of compiling teaching materials. Appropriate and typical cases are selected to enrich teaching materials. Try to combine theory with practice. Eventually improve students' practical and project operation ability. Third, we should pay attention to combination of teaching and practicing. When find a problem in the teachings, research it, use the result in the practice, and reflect the feedback in the teaxtbook. Form a virtuous circle of "teaching-research-business-textbooks". At the same time, strengthen the overall cooperation. Cooperate with related colleges, enterprises and research institutes. Avoid the dispersion and waste of research resources.

\subsection{Use a Variety of Methods, Strengthen Practical Teaching}

Practical teaching is the key to promote students' professional ability. We must implement it and ensure the 
teaching effect through various means and methods. First of all, strengthen the laboratory construction. Laboratory is the basic conditions to experiment teaching. Increase input of both software and hardware, construct necessary facilities such as computer and network, and develop and introduce intuitionistic teaching simulation system conforming to the enterprises' actual activity, which make students thoroughly grasp the operation and process of different jobs and modules and improve their ability to analyze and solve problems. Second, structure feasible electronic commerce teaching practice plan. The scheme is divided into virtual experiment teaching, practical teaching and entrepreneurship practice according to different phases of study. We can even encourage students to set up shop online. Practice e-commerce comprehensive project through contests of web page design, network marketing, sales, which can cultivate innovative ability and strengthen the understanding and experience of electronic commerce. Thirdly, flexiblely use modern teaching means such as multimedia and network teaching and other teaching methods such as case teaching, project teaching and online training. Increase teaching interest, improve students' perceptual understanding, enhance teaching quality and effect. Finally, strengthen construction of practical teaching base. Try the best to establish practice base in the enterprise, which lets students have the opportunity to participate in electronic business activities, realize e-commerce operation and combine theory and practice [7]. Make students contact enterprise before they step into society and understand requirements for the position.

\subsection{Improve Teachers' Level, Integrate Teachers' Team}

Electronic commerce is an applied specialty. A teachers team should be constructed which has reasonable structure, high teaching level and practice ability and satisfy the need of electronic business education, in order to cultivate talents [8]. First of all, improve teachers' ability. Let teachers "go out". The school should pay high attention to the training of teachers' professional ability. Send them to participate in relevant industry training and lecture (such as alibaba and taobao organizational training) and study in e-commerce enterprises. They can accumulate experience, improve professional practice skills and practice teaching ability. Second, hire industry elites to be teachers. Invite senior employees of electronic business (senior management or senior technical personnel) to give a lecture or hire them to be part-time teachers [9]. Masters or doctors who has high scientific research level and rich theoretical knowledge of electronic business can also be employed as part-time teachers. They can provide students with rich theoretical knowledge and precious industry practice experience. Finally, teachers should start from their own. Study more electronic commerce knowledge and grasps new teaching methods technology. Improve their knowledge and technical level through all kinds of ways.

\section{References}

[1] Feng, Y.Y. (2010) Problems and Solutions in E-commerce Teaching. Journal of Heilongjiang Administrative Cadre Institute of Politics and Law, No. 1, 23-26.

[2] Wu, Y.L. (2003) The Present Situation and Solutions of The Construction of E-commerce Subject. Science \& Technology Progress and Policy, No. 9, 42-45.

[3] Xie, L. (2011) The Discussion of Reformation of E-commerce Teaching in Higher Vocational Technology Colleges. China Electric Power Education, No. 17, 45-48.

[4] Qiu, C.H. and Zhu, X.S. (2011) Research of Electronic Commerce Teaching Mode Based on Trainings of Entrepreneurship. China Electric Power Education, No. 17, 29-33.

[5] Ge, H.D. (2005) Review and Reflection of the Construction of Electronic Commerce Teaching Materials. Vocational and Technical Education, No. 29, 35-39.

[6] Zhang, G.Y. (2005) Two Problems Puzzles Electronic Commerce Teaching. E World, No. 12, 35-37.

[7] He, Y.C. (2005) Discussion of Higher Vocational Colleges E-Commerce Practice Teaching. Modern Business Trade Industry, No. 15, 25-28.

[8] Fu, Z.Y. (2005) Research of Electronic Commerce Talents Training Strategy. Journal of Ningbo University (Education Edition), No. 2, 7-10.

[9] Wang, X.Y., Xiu, W.X. and Tian, L. (2008) The Construction of Applied E-Commerce University Teachers Team. Market Modernization Magazine, No. 28, 53-56. 


\section{Submit or recommend next manuscript to SCIRP and we will provide best service for you:}

Accepting pre-submission inquiries through Email, Facebook, Linkedin, Twitter, etc A wide selection of journals (inclusive of 9 subjects, more than 200 journals)

Providing a 24-hour high-quality service

User-friendly online submission system

Fair and swift peer-review system

Efficient typesetting and proofreading procedure

Display of the result of downloads and visits, as well as the number of cited articles

Maximum dissemination of your research work

Submit your manuscript at: http://papersubmission.scirp.org/ 